
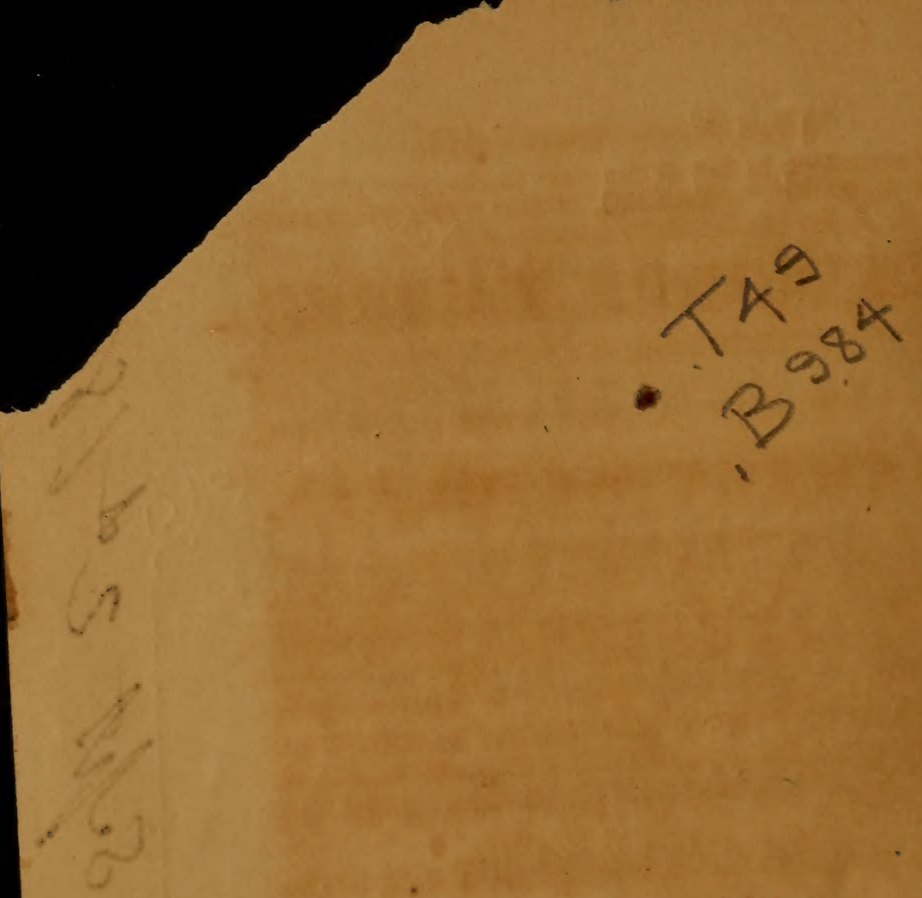

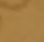

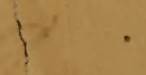

1
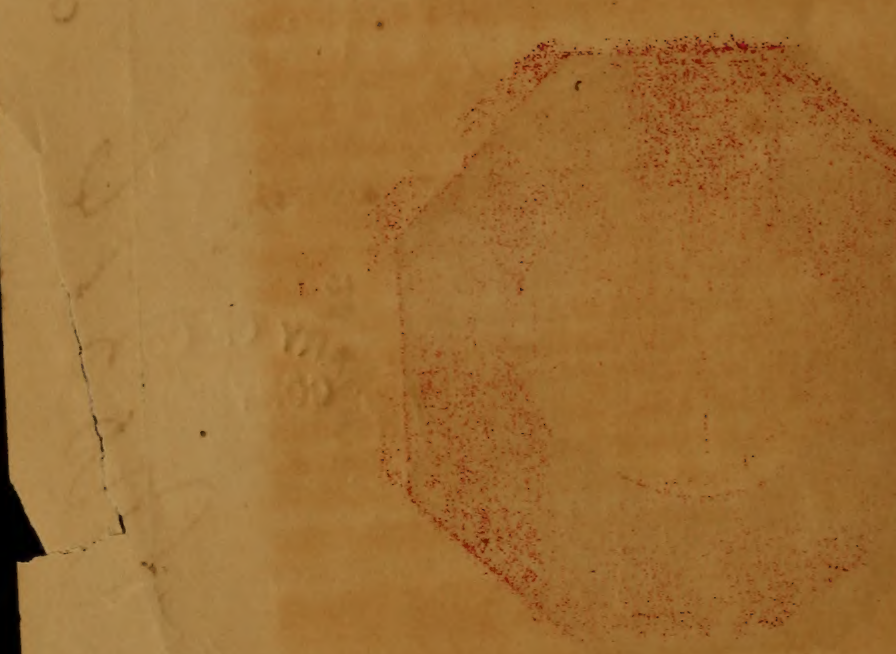
Entered according to Act of Congress in the year 1859, by Dr. M. L. BYRN, in the Clerk's Ofice of the Dis. Court of the U. S. for the Southern District of N. Y.

\section{THE MAGIC MLROR,} or,

THE ART OF

\section{ORNAMENTING GLASS.}

- This easy and cheap process of ornamenting glass with Paper is a pleasing and profitable employment. A thin paper is best, although you can use Lithographs, Pootographs, Steel Plates, Wood-cuts, Pen or Pencil Writing, or in fact almost anythiug on paper. By this process you do not transfer the copy Irom the paper, but let the paper remain on the glass, and it forms a beautiful frosting.

Prepare the glass by applying a thin coat of the preparation with a brush ; let it stand a day, or until it is dry, keeping it from the dust, then apply the preparation to the glass the second time, spreading it on thick. Let it stand 15 or 20 minutes, then place the copy smoothly on the glass, pressing it down firmly so as 10 exclude the air. If the paper is very thick, thin it on the back after you fasten it to the glass with a tooth or nail-brush, dipping the brush in water enough to keep the paper moist while you are thinning it. If you make the paper rough in thinning it, use a fine sand-paper to smooth it; then let it dry and get firmly set to the glass; then apply the preparation on the back to make it transparent.

There is no occasion for rubbing or thinning, unless the paper is thick.

If you wish to change the shade, place colored papers at the back.

Recipe for Preparation.-One ounce Balsam of Fir to one-half ounce Spirits of Turpentine. Mis and shake well together. 


\section{тин \\ - ARABIAN HORSE.TAMER.}

That obedience to man is a ruling principle in the nature of the horse; and theretore, to make him obey is not necessary to do violence to him. This disobedience is in fact forced upon him by conduct towards bim whicb does viol nce to his nature.

That to make him obey, it is only necessary to make hirn fully comprehend what is required of him.

That he has originality no conception of his own strength or powers; and,

That it is the part of wisdom to keep him in ignorance, which can only be dcne by mastering him without force; that is, by kindness.

That in the horse, as well as in man, fear is the result of ignorance; and

That, therefore, it is only necessary to accustom him to any olject of which he may at first stand in dread, to make him lose the sense of fear. Further,

That the best means of accomplishing this end is to allow bim to examine the dreadful object himself, and in the manner most natural to him.

All which amounts to just this: that the horse is an intelligont cresture, and that the only way to develop fully all hi- powers of usefulness to man is to treat him as such, and to convince him that his master is also his superior and his best friend.

\section{Characteristics of the Horse.}

\section{INDICATIOAS OF A HORSE'S DISPOSITION.}

A long, thin neck indicates a good disposition; contrarywise if it be short and thick. A broad forehead, high between the ears, indicates a very vicious disposition. 


\section{THE ARĀBLA}

The horse is unlike the dog, the bull, and most other quadrupeds, in two respects, both of which peculiarities run into one tendency. The horse has no weapons of defence, and hence is more dependent than other animals on his sense of smell for protection.

It is remarkable that, unlike other animals, the horse breathes only through his nostrils, and not through his mouth, like the ox and the dog.

\section{Mechanical, Medicinal, Psychological.}

Each of these terms is necessary in describing all that is comprehended in the philosuphy of taming and training horses. The horse, like other animals, is controlled by memory and the laws of association.

Hence he must be reached through one or exch of his external senses-smell, sight, hearing, and fecling, and when they are reached, he may be conirolled by mechanical force, and especially by psychology and the laws of association.

10 "For the mechanical process you will need a strong leather strap, three or four feet in length, with a buckle; also a pole (a fishiug-rod)-the longer the better. On the end of the pole you may wind and fasten a small slip of cloth.

"For the medicinal you will need the oil of rhodium, oil of cummin, or oil of anise-seed. These should be kept in air-tight phials ready for use.Have also in readiness the horse-castor, grated fine.

"That which partakes of the psychological you will find in your own mind,-your own love, will, and wisdom. If you have little or no instinctive love for the horse, of course you are not the person to control him. Men and women are often found who are said to have the natural gift of controlliug the horse; they love horses from instinct, as it were. The secret in these cases consists in their intense love for the horse. If you love the horse, you will, you can, bat know how to make the horse love you. Love in all grades of animals bas its appropriate language; and when this lan- 
guage is addressed to the horse, it excites love, of course. A blow with a whip or club does not coms from love, but from combativenes:, and it excites combativeness or fear in the horse. If you want to make a horse love you (and you must cause him to love you if you control him), why, of course, you must love him and treat him accordingly.

"Study the character of your horse, not the mature of horses in general, but of the horse you wish to control. Horses differ in their dispositions ats really as men do; and each one is to be approached, attracted, pleased, and controlled accordingly.The organs in our way are Fear and Combativeness, and both these functions are excited through tha sense of smell. Observe that these objects again:t which this sense of smell warns the horse differ verg much. One object or person may be offensive to one horse, another object to another.

\section{To Catch a Wild Horso.}

2. "If your horse be in the field, he raust he cor. nered;" drive him into a gard, into the corner where he cannot escape. R!!b gour hands with tin oil of cummin, or rhodium : have your poie, with the small piece of cloth wound on the further end. which must smell also of the oii. Aiproach hin from the windward, and you mag thus attract him, even before be is in the reach of ycui pole. Pro ceed gently until you can reach his back with the end of your pole. It is precisely as if your a: $n$ were elongated to the length of your pole; $\mathrm{sul}$ ! vou pat him and work and move the pole over his biuk. gradually and gently approaching his bead. And thus, by passing the pole up and down bis baik, and occasionally carrying the end near his nose, ho is attracted by the sense of smell, so that you may slowly shorten the distance between you sico tlio horse, until you can with your band rili a lit:le vil of cummin or rhodium on his nose ; and this done, you can with suitable assistance put on the bridlo or halter, and thus secure him. A failure for a few 
times should not discourage you ; repeat the process until you succeed. And if you fail with one of the oils, try another. With some horses you may succeed best by mixing equal parts of the oil of rhodium and anise-seed. A small quantity of the rhodium may be dropped upon the grated castor, after it has been sprinkled upon an apple or a lump of sugar, and given him to eat; and rabbing his nose' with either of these oils, and, at the same time, breathing into his nostrils, will often work like a "charm." But then it should be borne in mind that there is a difference in horses as really as in human beings. Horses that have large caution or fear, it is, of course, much more difficult to control. But the agreeable excitement of the sense of smell overcomes the sense of fear; and fear once subdued, it enables you to render your sphere agreeable to the horse, so that you may compel him to do your bidding.

\section{To Hake a Horse lie down.}

First catch your horse, then strap the near foreleg up round the arm of the animal; lead him about on three legs until he becomes tired or weary; he will then allow you to handle him anywhere; thon attach a strap with a ring to the off fore-fetlock; to this ring fasten another strap, which being brought over the horse's back to the near side, is put through the ring on the off fore-fetlock; return the end of the strap to the near side, keeping fast hold, and move the animal on, and pull; he will then be thrown upon his knees, when, after struggling some time, by gentle usage he will lie down. After unloosing the straps, put him through the same process as before, when the horse will lie down whenever required.

Uniformity is necessary in our method. It is by the repetition, by the constant recurrence of certaiu motions, words, or actions, that we succeed. Many fail for the want of uniformity in their method.They are loving and kind by spells; then they are warh and cruel. The horse is "impressed," (ns it is 
said, with his master's wishes, when those wished are often and uniformly expressed in motions, words and deeds! If man needs "precept upon precept, line upon line," \&c., in order to learn bis lessons well, now much more true is this of the horse, which is below man in consciousness and the reflectivo faculties.

\section{Plan of Driving the Wildest Horse.}

This is easily effected, by fastening up one foot. Bend the leg inward, so as to bring the bottom of the hoof neatly up to his body, and slip a strap over the jont, and up, until it is as high as the pastemjoint, at which you must have another small strap, to which the larger one must be fastened, so as to prevent it from slipping down. Your horse now stands on three legs, and you can manage bim as you please, for he can neither kick, rear, run, or do any thing of a serious a ature. This simple operation will conjur a vicious horse quicker than any other way.

\section{Teaching a Horse to Pacs.}

Buckle four pound weight around the ankles of his hind-legs (lead is prefierable), ride your horse briskly with those weights upon his ankles, at tho same time twitching each rein of the bridle alternately, by this means you will immediately throw him into a pace. After you drave trained him in this way to some extent, change your leaded weights for oomething lighter; leather padding, or somethiug equal to it will answer the purpose; let him wear these light weights until be is perfectly trained.This process will make a smooth and easy picer of any horse.

\section{Horsemanship.}

The rider sbould, in the first place, let the horse know that he is not afraid of him. Before mounting a horse, take the rein into the lelt hand, draw it tightly, put the left foot in the stirrup. and raise quickly. When you are seated, press your knees to 
the saddle, let your leg, from the knee, stand out; turn your toe in and heel out; sit upright in your saddle, throw your weight forward, one-third of it in the stirrups, and hold your reins tight. Should your horse scare, you are braced in your saddle, aud he cannot throw you.

\section{To Kake a Horse Stand.}

This lesson is to be first in the stable. Having put your bridle on, drop the reins over his neck, and commence caressing his face, and gently work backward until you take hold of his tail. Hold on to it, and step back till you are to the length of your arm, then gently let his tail fall, and forming a half circle, waik back to the head, all the while repeating, "Ho, boy!" Pat his face, rub his eyes, and again pass backward, and this time form a complete circle round him, but so near as to keep your hands on him. Continue to enlarge your circle, until you get off as far as the stable will allow. When he will stand still in this way, you can take him out on a lot and go through the same manipulations.

\section{To Make a Horse Set on his Haunches.}

First learn the horse to obey you, so that when you say "Ho!" he will remain still. Then, having learned him to lie down, let him get up on his forelegs, and then stop him. The horse gets up in thia way, and you have only to teach him to hold his position for awhile. It does not strain the horse ta set, and you must always use the word "set" ia connection with the feat. Also the word "down"s when you wish him to fall.

\section{To Hake a Horse come down for Mounting}

Stand by bis side, and stooping down, put up ono of his feet, set it as far forward as you can, to make him keep it there; then take up the other and put it forward as far as you can, not to have him put it up again. Then with a small stick lightly tap hitn 


\section{THE ARABIAN HORSE-TAMER.}

on the back of the leg, near the pastem-joint, first one leg, then the other, he will soon put them a little farther forward, and then you may in the same way spread out his hind-legs. Continue this, day after day, until he will come down enough at tho word "Lower." This trick is easily taught a young horse; but remember, it injures him to often mount him thus spread out.

\section{To Make a Horse follow you.}

Take your horse to the stable, put on a circingle and a bridle with short reins, which may be checked up a little and fastened to the circingle. Then lead lim about a few times, and letting go the bridle, continue to caress bim, as you constanily say "coine s. long." If he lag, give h $m$ a light cut bebind with s long whip. Continue this unil you succeed. Do I ot forget the element of "LOVE" in this as well as 1 ther feats.

\section{How to Handle Horse's Feet.}

Should the colt refuse to have his feet handled he may be made to submit by reproving with the bridle and putting a small strap on the hind hoof; then pull on this strap and bring the foot up ; then at the moment he kicks bring down on the mouth sharply with the bridle. In a short time be will submit to your control unconditionally. The same principle applies to the use of this under all circumstances. It is a means of reproof, and certainly has a powerful efiect upon a horse. 
Horo to malse Saur $\boldsymbol{K}$ raust. - Take a large strong roodon vecol, or cask, resembling a salt beef cask, and ci pable of containirg as much as is sufficient for the winter's consumption of a family. Gradually break down or chop tho cabbages (deprived of outside green leaves,) into ver: omall pieces; begin with one or two cabbages at the bortom of the cask, and add others at intervals, pressing them by means of a wooden spade, against the side of the cask, antil it is full. Then place a heavy weight on top of it and allow it to stand near to a warm place, for four or $f$. days. By this time it will have undergone fermentation; ond bo ready for use. Whilst the cabbages are passing through the process of fermentation, a very disagreeable fetid, acid smell is exhaled from them; now remove the cask to a cool situation, and keep it always covered up. Strew Aniseeds among the layers of the cabbage during its preparation, which communicates a peculiar flavor to the Saur Kraut at an after period.

In boiling it for the table, two hours is the period for it to be on the fire. It forms an excellent nutritious and antisoorbutio food for winter use.

How to mend a Stove. - When a crack is discovered in a atove, through which the fire or smoke penetrates, the aperture may bo completely closed in a moment with a composition consisting of wood ashes, and common salt, made Into paste with a little water, plastered over the crack. The good effect is equally certain, whether the stove, \& $c_{\text {, }}$ be cold or hot.

Bed Bugs. - A strong decoction of ripo red Pepper in aid to be as efficacious an antidoto to Bed Bugs as can bo selected from the multitudinous recipes for tho purpose.

Burning Fluid.-Take four quarts of Alcohol and on quart of spts of Turpentino-mix well together.

To Extract Paint from Cotton, Silk and Woolen Goods.- Saturate the spots with spirits of Turpentine, and let it remain several hours, then rub it betwoen the hands It will crumble away, without injuring eithor tho color, ot coxture of the article. 
To males Apple Jelly. - Tako of Applo Juioe [strained] a lbs. Sugar 1lb. Boil to a Jelly.

Stravberry Jelly. - Take of the Juice of Strawborrie 1 lbs, Sugar $1 \mathrm{lb}$. Boil to a Jelly.

To Avoid Injury from Bees.-A wasp or bee swal. lowed may be killed before it can do harm, by taking 8 teaspoonful of common salt dissolved in water. It kills the insect, and cures the sting. Salt at all times is the best curo for external stings; sweet oil, pounded mallows, onions, or powdered chalk made into a paste with water, are also efficacious.

If bees swarm upon the head, smoke tobaceo, and hold an empty hive over tho head, and they will enter it.

How to Make Rose Water.-Take half an ounce whito vagar, and drop into it 2 or 3 drops of Otto of Kose; then grind very fine in a mortar. After it is well ground into fine powder, pour on it half a pint of cold water, grind well for a few moments, and then mix it all with one gallon of cold water. Let it stand for 3 or 4 days, and strain through fine muslin.

Whiterocshing.-A pint of Varnish mixed with a bucket of Whitswash, will give it in a great degree, the qualitie of paint-and it will withstand all kinds of weather.

Nankin Dye.-Take Arnotto and prepared Kali, equal parts, boiled in water; the proportion of Kali is altered, as the color is required to be deeper or lighter;-used to restore the color of faded nankin clothing, or to dye new goods of a Nankin color.

To make Spice Bitters.-Golden Seal, Poplar Bark Bayberry, bark of the root, Sassafras, bark of the root, of each one pound; Unicorn Root, Bitter Root, Clovea Capsicum, of each, four ounces, Loaf Sugar, four pounda Put to one ounce of this powder, one quart of sweet wing let it sttnd a week or two before using it. Dose-a wino. glassful two or three times a day. 
TALOABLB RECIPES.

Armenian Cement.-Soak Isinglass in water till coft then dissolve it in Proof Spirit, add u little Galbanum or Gurn Ammoniao, and mix itıwith Tinct ro of Mastick.

It must bo kept well stopped, and $w_{2}$. wanted, liquo . fod by the phial being immersed in hot viater. Used to cement jeweis upon watch-cases; to mend china, or to roplaco leaves torn ont of books.

To prevent Flies from Settling on Pictures, Picture Frames, or other Furmiture. - Soak a large bundle of Leeks for five or six days in a pail of water, and then wash or sponge the pictures, \&ce. over with it.

A wash to be used to the Arm-pits when the peropiration is unpleasant. - Take pure spring water as cold as can be got, 2 pints; Tincture of Myrrh, 1 ounce; Sulphate if Zine, 1/2 ounce; Rose Water; 2 ounces. Mix all together and sponge the arm-pits occasionally with it.

To cure Butter. - Take 2 parts of the best common Sak, one part of Sugar, and one part of Salt-petre. Beat them up and mix well together. Take one ounce of this to overy pound of Butter, work it well into the mass and close it up for use.

Butter thus cured, appears of a rich marrowy consistencs and fine color, and does not acquire a brittle hardness, nor taste salt. It will keep good frr three jears, if let stand three or four weeks before openisg it.

To Moderate Perspiration.-Take Spring Water, 4 ouncos; Diluted Sulphuric Acid, 40 drops; Compound Dpirits of Lavender, 2 drachms. Mix. A table-spoonful twice a day; keeping the bowels regular by Rhubarb.

Wash to Whiten the Nailo.-Take Diluted Sulphurio Acid, 2 drachms; Pump Water, 4 ounces; Tineture of Myrrh, 1 drachm. Mix. First cleanse with white Soap, and then dip the fingers into the wash.

Sore Thro:-Let the Throat be steame d rith Hot Wa tor, in which Hops are infused ; apply the Hops, after having been scalded so ne time, externally to tho dissased part of the throat. 
TALUABLÉ RECLPE3.

To join Giase together.-Take a littlo Isinglass, and melt it in spirits of Wine ; it will form a transparent glue, which will unite glass, so that tha fracture will be almost imperceptible. The greatest cere is necessary, that the pirits of wine shall not boil over into the fire.

To Renovate old Apple Trees.-Take fresh made Lime from the kiln, slake it well with water, and well dress the sree with a brush, and the insects and moss will be completely destroyed; the outer rind fall off, and a new, mooth, clean, healthy one formed, and the tree assume a most healthy appearance and produce the finest fruit.

To prevent the Smoking of a Lamp.-Soak the wick in strong vinegar, and dry it well before you use it; it will then burn both sweet and pleasant, and give much satisfaction for the trifling trouble in preparing it.

To make Silvering Puroder.-Get from a Drug Storo $1 \mathrm{oz}$. of what is called Hydrargirum, Cum Creta, and mix it with 4 oz. Prepared Chalk. Used to giro a Silver Polish to Brass, Copper, Britannia Warc, \&c. To be rubbed on with a dry cloth.

Nerve Ointment.-Take half a pint of Neatsfoot oil, one gill of Brandy, one gill of spirits of Turpentine and simmer them together fifteen minutes. Excellent for sprains, owellings, and Rheumatism.

To free plants from Leaf-Lice.-Mix 3 ouncec of Flowers of Sulphur with a bushel of Saw-dust; santter this over the plants infested with these insects, and they will soon be freed, though a second application may possibly le necessary.

To Preserve Eggs.-Apply with a brush a solution of Gum Arabic to the shells, or immerse tho Eggs thereinlet them dry, and afterwards pack them in dry charcoal dust. This is vastly superior to the plan of putting Eggs ap in lime, as the lime makes the shells brittle, and the Aan on worthless, but the Gum process prevents b p siuc effected by changes in the atmosphere. 


\section{Human Frailty.}

Is all ages of the world, of which we have any accornt, there has prevailed in the youth of both sexes a most destructive habit, by reason of which many thousands of lives are lost every year, besides in innumerable instances the laying the foundation for disease and a debilitated condition, which the best efforts of a life-time do not counteract. This habit is known by the name of secret habits of youth, or masturbation, and is one of the most prevalent, the most universal and destructive of any that afflicts the human race. One reason why the yice, or habit, is so very destructive to youth is, from the fact that it. is continued in secret from day to day, and from year to year, without a knowledge of its real consequences. There aro very few parents who ever think to warn their children of the dangers of this habit, either by speaking to them, or putting into their hands a treatise on the subject, and even do all in their power to keep their children from getting hold of any books on the subject. This kind of false modesty has been the cause of many a bloom. ing youth filling a premature grave, and wo hope to see the time when parents, teachers, and guardians, will treat those entrusted to their care with more confidence and the exer. cise of better judgment.

This habit, began in youth, is often continued many years, even to the age of thirty years or more.

However, it is not ALIVAys the result of initlation, or contracted by contact with those who indulge 11 the habit, but this is the cause in 
most cases, and one bad boy will ruin twenty good ones. There are those who think their children can only contract bad habits by contact, and among the rest the habit of masturbation, and think that if they can keep their families from vicious company they are safe. This s generally true, but there are exceptions to $\boldsymbol{t}_{i \theta}$ rule, for no matter how strict a parent may - e, the very innocence of a child makes him a ready tool for the designing, when they diance to fall into their company. It would take too long to narrate the many phases and peculiarities of the thousands of cases I have treated in the last few years. This terrible habit is oftener learned at school than elsewhere; more than half of my patients having told me that they were taught it while going to school. With these facts before us, is it to be wondered at that libertines and masturbators become effeminate, and injure their constitutions, and that girls lose their beauty, their. charms, amiability, the delicacy of their forms, and sweetness of voice? The following are some of the consequences of this destructive habit:

That most fatal disease, consumption, is often induced by this habit by debilitating the system, and causing tabercles to be developed in the lungs.

Loss of memory is among the most common effects produced by it. Nearly all my patients complain of this, who have indulged in mastur. bation.

Insanity is sometimes produced by this habit; the unusual and unnatural excitement produced 
by the very frequent repetition of the act sooner or later reaches the brain, the great nervous centre, unless abstained from; and this weakness continues in a ratio with the extent to which the practice has been carried, until it no longer controls the body, and there is lowness of spirits, a disposition to commit suicide, as many patients have informed me, restlessness, discontented mind, and an exceedingly unhappy irritability of temper, causing the patient to make himself and everybody around him unhappy.

An uneasy aching pain, heaviness, and weakness across the back and loins, is a frequent symptom, especially in the morning.

Palpitation of the heart, shortness of breath, and nervousness, also result from masturbation.

A nervous aching pain in the head, bones and muscles, resembling rheumatism, is a frequent consequence. By weakening the general powers of the system, masturbators have not the ordinary powers of resisting diseases, and for this reason, as soon as they expose themselves to an atmosphere tainted with ordinary epidernic poisons, such as fevers, \&c., they are more liable to the disease.

A thin, watery, or gleety discharge, frequently occurs, in old cases, showing extreme weakness and wasting of the parts.

A gradual wasting away of the testicles, and entire loss of vitility, is a common occurrerice with persons long addicted to this secret habit.

A very frequent desire to pass the urine, and an inability to hold it, are the frequent results of masturbation;-sometimes, however, they 
cannot pass the urine without the aid of a catheter to draw it off. Stricture or narrowing of the passage is produced by this habit, thus laying the foundation for an untold amount of nisery and suffering.

In females, the following diseases are proanced:-Whites, loss of sensation, falling out of the hairs and eyebrows, bad breath, loss of the natural voice,-barrenness, falling of the womb, epileptic fits, ulceration of the neck of the womb, \&c. The most fiequent disease produced by masturbation in males, is called spermatorrhœa, or involuntary emission during sleep. These at first are rare, happening orly in the course of two or three weeks, and takes place during a dream of a lascivious character. -They snon become more frequent, and if accompanied by a dream, they do not wake the person, and fina!ly they happen almost or quite without any sensation.

Having described the nature and symptoms of this vice and its effects on the system, wo would now beg to offer you our advice as a medicai man. But the delicate nature of the advice is such as could not with propriety be inserted in these columns, as it is intended for all classes. This advice, then, can only be given to each person individually, according to the amount of damage the srstem has sustained, the length of time it has been practised, the peculiarity of the constitution, the age of the patient, dec. The treatment which might bo good fur one individual, wight be of no servico whatever to another, and under these circum. stances, the ouly safo plan for every person 
who has been guilty of this practice, is to consult a physician immediately. I offer you my services on the "live and let live" principle, and in the reach of all. In a private circular which I send to all such as apply to me for advice on this disease, [or vice, as you may choose to call it,] the most explicit directions are given, and along with this, medical treatment, which at once puts vitality into the system, and speedily restores the parts to a liealthy state, if directions are followed. By consulting me immediately, you may save yourself from much suffering, uneasiness of mind. and be restored to health.-If you go on, you may make of a once stout and robust frame, a total wreck, unfitting yourself forever for the married state. Do not risk all this for the sake of a few dollars, but write to me at once and give a full history of your case, and rest assured I will endeavor to be your contidential friend and benefactor.

D㮃 All letters destroyed as soon as ansivered. Persons visiting the city, who prefer to do so. can call at my office No. 80 Cedar Street,

between $9 \mathrm{~A}$. M. and 4 P. Y., or enclose the amount in a Registered letter, directed to Dr. M. L. Brre, Box 4,669 P. O., N. Y. City. Every thing can be sent so that no one can tell it from an ordinary letter, and is carefully sealed up. Do not feel any delicacy in consulting me, but speak as to a friend-I will try to do you good.

Persous wishing advice or medical trentment, will please answer the following questions on the first application. At what age did you be- 
gin this habit, and how often indulged in, how long continued, and, if abandoned, how long since? Is your system much weakened? Are you nervous and irritable? Have you short ness of breath or palpitation of the heart? Is you have emissions, how often, and do they weaken you? Do you have any heat or unnatual feeling, tingling fullness, or other trouble in he parts? Have you scalding or pain in making water, and do you urinate naturally and free? Is the nrine of natural color? Wha is your general health, the state of your appe tite and condition of your bowels? Your age occupation, mode of living, and have you an. predisposition to consumption or other diseases Married or single?-Do you lose semen during a movement of the bowels? Do you lose semen AFTER passing urine? Is the memory much impaired?

Persuns applying by letter for treatment, will please enclose FIVE dollars, and 25 rents for postnge, and I will forward medical treatment by return mail.

When desired, the medicines can be sent by Express.

All letters must be plainly written, giving the name of the person, or initials, the Post Office, County and State, and be addressed to Dr. M. I.. BYRN, Box 4,669 Post Office, New York City, office No. 80 Cedar St. 


\section{CONDEMN NO MAN WITHOUT A TRLAL. "PROVE ALL THINGS!"}

\section{"Hold fast that which is good."}

I am aware that in issuing a pamphlet like this to the public, and sending copies thereof broadcast thruughout the length and breadth of our country, that I have much to contend with in the way of public prejudice. It is true that persons calling themselves physicians, have issued flamin circulars, represeuting what they could do and what they would do, for the afflicted, and that they have grossly swindled many persons, defrauding them, and getting their money without complying with their specious promises. This has been the case in this, as in all other large ci. ties of the civilized world. And yet that does not argue that there are not honorable, highminded, and competent pbysicians, who prefer to issue a medical pamphlet, circular or public journal, and thereby make themselves more widely known, and bring the peculiar medical skill which they have acquired by long years of stu$\mathrm{dy}$, research and practice, before the people, that they may reap a commensurate reward, rather than plcid along in a professional career which promise a " head whitened o'er with the frost of many winters," before they expect to get a ' paying practice,' which, by the way, comes in just about the time of life when the physical energies are well nigh exhausted.

It is right that in catering for public patronage and favor, by coming before the people, as I do, that I should let it be known who I am. I take pleasure in doing so: I have been engaged since 18533, in the practice of my profession, in the city of New York, but not being of a robust 
constitution, I have confined myself to "office practice," and consultation by letter, that being less laborious, and better suited to my physical condition. During this time I have written. edited and compiled altogether about thirty different. books, some of which have been published in $\mathrm{New}$ York, Boston, Philadelphia and Cincinnati, by the most respectable publishers in the country, and the others I have published myself.

I ha ve also during this time edited and pub lished the " United States Gazeite," a large monthly newspaper, (for seven years.) And for a number of years past have beon publishing the "Nevo York Medical Journal." I have also been manufacturing and selling for many years past, valuable " proprietary medicines," which have given better general satisfaction than any other medicines I have known of. My rule has been to deal strictly on the live-and-let-live principle, paying Cash in all my business transactions, and never meddling with the business or concerns of other people.

I have tried to deal honestly and fairly with all men, and have not intentionally given cause cause of offence to any living being; and I can defy any man to say that I owe him one dollar, or that I have ever beer guilty of a dishonorable act.

I am a graduate of the "Medical Department of the University of the City of New York,,"-see copy of Diplonin-and pay my dues to the Governjnent under which I live, and I am an American citizen, being a native of the State of Tennessee. I am over 40 years of age, and have a wife and children, for whose welfare and happiness it affords me pleasure to labor. I am a niember, and have been for many years, of the " Methodist Episco- 
pal Church," and have never brought reproach on the church of my choice, or the religion which I profess.

I would respectfully refer to the numerous recommendations published elsewhere, and solicit from my fellow citizens in all parts of our country, a continuance of their patronage.

MARCUS L. BYRN, M. D., No. 80 Cedar Street, New York.

\section{$\longrightarrow r-\cdots$ \\ A VALUABLE MEDICINE. \\ DR. BYRN'S \\ Compound Extract of Buchu.}

No one Medicine, perhaps, has been more extensively advertised than wxeract of Buchu, and none that has a larger sale. Ic has remarkable medicinal qualities. The "United States Dispensary," considered among the best medical authority in the world, on the article "Buchu," has the following words of commendation:

"This Medicine consists of the leares of plants growing at the Cape of Good Hope. These leaves are collected by the HotrexTOTS, who value them on account of their odor, and, under the name of Booroo, rub them in a state of powder upon their greasy bodies. * * Buchu leaves are gently stimulant, with a " pecu. liar tendency" to the urinary organs. The Hottentots have used them in a variety of diseases. * * They are given chiefly in diseases of the urinary organs, such as GRAVEL, Chronic CA. TARRH OF THE BLADDER, morbid irritation of the Bladder and Urethra, disease of the Prostate Gland, retention or iucontiuence of urine from loss of tone in the parts. The remedy has also been recommended in Dyspepsia, Chronic Rheumatism, and Cutaneous affections."

It will be seen by the above high medical authority, that there is real merit, positive curative properties in Buchu. Now, the question is, can the medicine be oblained pure? and if so, at a LIVING Pilck? I must say frankly, that a large share of the Extract of Buchu, so CALLED, which is sold in this country, is 
nothlng but Extract of Liquorice, scented with a tincture of Bu chu leaves.

Now, under these circumstances, it will be seen that it is highIy necessary to get GENLINE Extract of Buchu, to be benefitced l.y its use. I have prepared an article that I wakksNT GENU. INE CUMPOUNU EXIRAC' UF BUCHU! It is put up in Boxes, instead of Bottles, and each box contains enough of the medicine in powder to make one quar $t$ of the kixtract. Ail that is necessary for those who wish to use it, is to put the powder in to a buttle and add some water and spirits to it, and it is reaciy for use. It will be observed that one box of my GENLINE Extract of Buchu. which costs only 50 ets., makes as much as you would get for $\$ 5.00$ in bottles ready made, making it the cheapest mediciue in the world.

This COMPOUND EXTRACT OF BUCHU is a valuable remedy in all forms of diseases of the genito-urinary organs, even in those cases of long standing, such as weaknesses aristng from sexual excesses, habits of dissipation, early indiscretion, \&c., attended with the following symptoms :

In disposition to Exertion, Loss of Memory, Weak Nerves, Hor ror of lisease, Dimness of Vision, Hot Hands, Dryness of the Skin. Uiviversal Lassitude, Loss of Power, Difficulty of Breath. in., Trembling, Wakefulness, Pain in the Back, Flushing of tho Kodj, Eruptions of the Face, Palide Countenance.

For Sexual Diseases (or secret diseases as they are oftentimes called) this is a lenelly of great va'ue, at but little expense, little or no change of diet, and no inconvenience or exposure. It is equally good lor all affections of the organs whether existing in male or female, from whatever cause produced. Diseases of these organs require Diuretic Medicines to operate through the Kidneys and cause an increased flow of urine, and this COJPUUND EXTRACT UF BUUIIU is the great Diuretic, and as You will see, is recommended by the highest medical writers. for all the diseases of the Bladder, Kidneys, etc.

It is a medicine of peculiar benefit to old men, who are often troubled with diseases of the urinary organs.

Price 50ats., sent free of postage by mail. Send Cash to Dr. M. I, B Y kN, Bux 4,6ig P. O. New Íork. Office No. 80 Cedar otreetio 


\section{MEDICAL EDUCATION.}

As there are so many impostors in large cities-men pretending to be physicians and surgeonz, and have never been proverly qualified to act in such capacity, I have conclude d to produce the evidence for the information ard benefit of those who do not know me personally, of my Medical Education having been regularly completed in one of the first Medical Schools in America. I trust that hereafter. persons wishing to consult me, will be :atisfied that they are placing themselves in the hands of a regula ly edncated physician. The followi $\mathrm{g}$ is a copy if the DipLoma (tratislated) awarded to MI. I. BYRN by the University of the City of New York, March 3d. 1851:

"The Chancellor, Prolessors and Council of the University of the City of Nerv York--To all and singular, the persons reading these writings, wishing contiaued health in our Lord Jesus Chist--Be it Known, that it lias pleased us under the authority best tomed by public charter iu this institution, 10 adurn M. L. BYr N. an u: right man, in the first plice having undergone an examisation, im. bued with the excellent ait of medicine and science of surgery, with the title and degree of Doctor of Medicine, and to grant to him all rights, honors and privileges pertaining $t$, the said deg'ee. In 'T'es'imory, thereof, we affix to these letters of thiss University the seal and our handwriting. Given from the bnildings of the University of New York, the $3 d$ day of March. 1851, and of the independence of the United States, the 73d." (:IGNED)

JOHN W, DRAPER, Chancellor.

GRANVILLE S. PATTISON, M. D. Professor of Anatomy.

MÁRTIN PANNE, MT.D ,Prnfessor of Miateria Medica and Therapeutica.

12 JOHN W. DRAPER HI.D Professor of Chemistrv and Physiology.

E. BARTIETT, M.D , Professor of the Institutes and Practice of Medicine.

G S BEDFORD, M.N., Professor of Obstetries.

S. D.GROS3, MI. D , Professor of Surgery.

$$
\text { Council, }\left\{\begin{array}{l}
\text { JOHY C GREEN, Prosident. } \\
\text { WILLIAI B MIACLAY, See'y. } \\
\text { A. C. KINGSLAND, Mayor. }
\end{array}\right.
$$




\section{The Art of Beantifying the Hair,}

With Rules for promoting its Growth and Preservation.-By M. L. BYRN, M. D.

This valuable book teaches how to Gloss and Curl the Hair. How to make Curling Fluids, \&c. How to use Curling Irons without injury, \&c. How to put up the Hair in Papillottes. Rules for Dressing, Curling, Twisting and Plaiting the Hair. How to Comb and Brush the Hair correctly. It tells you why the Hair turns Grey or falls out, \&c. It gives you the remedies for Grey Hair. It teaches you the causes of Baldness, with the remedies therefor. How to cultivate the Beard, Mustachios, and Whiskers, and rules for beautifying them. It gives the rules for proper principles of Shaving, and how to avoid inconveniences in the use of the razor. How to cultivate long eye brows and eyelashes, and rules for beau ifying them, \&c. How to make various kinds of Hair Oils. Hair Dyes, Pomades, Hair Powders, Perfumes, \&c., \&c. Also, other valuable information we have not room to enumerate.This book is warranted to give satisfaction; sent by mail, free of postage, for 25 cents.

Direct all orders to Dr. M. L. BYRN, Box 4,669 Post Office New York City.

\section{DR. BYRN'S}

\section{Core for Fimples or Worms in the Face.}

Warranted to be entirely harmless, is used without any trouble, and leaves the skin soft and smooth, if used according to directions. Price only 30 cents a package, or four for $\$ 1.00$. Sent in a letter, free of postage.

Send Cash to Dr. M. L. BrrN, Box 4,669 Post Office New York. Office, 80 Cedar Street. 


\section{VARECDCERT.}

Almost the first symptom produced either by masturbation or excessive sexual indulgence, is a fiabby, relaxed condition of the parts; the privates hang lower than usual, the spermatic cord is relaxed, and there is a dull, aching, heavy, dragging feeling in the parts, with sometimes, in more advanced stages, pains shooting up occasionally into the groin and lower part of the abdomen, and also a heavy aching feeling in the small of the back. There is enlargement on one side, usually the left, and the scrotum feels like a hag of worms. There is pain, and at times a coldness and numbness in the privates. The parts should be immediately strengthened, and kept in their proper and natural position. With this view I have prepared a " Medicated Bandage." I would especially recommend those who have applied for medical treatment for masturbation, or effects of sexual excesses, to get one of these bandages.

Also, men advanced in life, would be benefitted by wearing one of these bandages.

Sent in a letter free of postage for Two Dollars. Direct all letters to M. L. BYRN, M. D. Box 4,669 Post Office New York City.

\section{$\longrightarrow 0$ \\ Dr. Byrn's Cure for Rheumatism.}

This is prepared on strictly Scientific Principles, and is adapted to the cure of Old cases of Chronic Rheumatism, which ordinary remedies do not cure, as well as the ordinary cases of this painful disease. Warranted to give satisfaction if directions are followed. Price only 50 cents a package. Sent in a letter free of postage.

Send cash to Dr. M. L. BYRN, Box 4,669 P. 0. New York, (office 80 Cedar St.) 


\section{The Physiology of Marriage, AND}

PHILOSOPHY OF GENERATION,

C MARRIAGE GUIDE FOR EVERYBODY.

BY M. I. BYRN, N. D.

Our happiness, or our misery, in this life, greatiy depends upon our being happily matched in marriage. Whom to marry, when to marry, how to tell beforehand what kind of person we are making love to, whether kind, gentle and loving, or morose, cross and fretful; whether industrious or lazy, faithful or false; whether they will bo healthy or sickly-in fact, a thousand things of vital importance to the married, or those contemplating marriage, on this subject should be known. Now, how are you to know them? Send 25 cents for this book, it tells you all about this important subject necessary for you to know. It is a private and confidential friend, for reliable medical and scientific consultation on a subject of vital importance, and has a word in season for all classes, ages, sexes, and conditions of our race. Single copies 25 cents ; sent by mail free of postage.

All orders must be sent to

DR. M. L. BYFN, Box 4,669 Post Office, N ew York. Office, 80 Cedar St.

\section{Dr. Byrm's Cure for Piles.}

This painful affection is relieved in a few moments by this remedy, and is permanently cured by following directions in a few weeks. It is used for Blird or Bleeding, Inward or Outward Piles, with entire safety, and satisfaction is warranted. Price 50 cents a package. Sent free of postage.

Send Cash to Dr. M. I. Byrn, Box 4,669 Post Office New York. Office, 80 Cedar Street. 


\section{THE SECRET OF REAUTY.}

\section{oR \\ YOUMG PEDPLE'S BOQK.}

This book contains directions for removirg Freckles, Tan, Sunburn, Discolorations, Moles, \&s. Also how to beautify the Complexion, Soften the Skin, \&c. How to make Ferfumes, and the various articles for the Toilet, the wardrobe and the pocket, for ladies and gentlemen. How to preserve and beautify the Teeth; to cure Chap. ped hands, Lips and Face; to cure Ringworm and Frostbite or Chilblain; to cure Pimples. Warts, Wrinkles, Corns, \&c. ; how to have bright eyes and rosy cheeks. Directions how to make tooth powder, Camphor Cream, Lip Salve, Flesh Powder, Colozre Water, Honey Water, the Delectable Odor, Javender Water, Macassar Oil, Lip Foney, Balm of Mecca. \&c. This is emphatically the Young Peoples' Book.

Price only 15 cents a copy - sent in a wrapper: secure from observation, postage paid. Send or: ders to Dr. M. L. Bry:r, Box 4,669 P. O. New York City. Office, 80 Cedar Street.

$$
\text { DR. M. L. BYRN'S }
$$

\section{Halcyon Mue or Hair Tonic,}

For Preserving and Becuififying the Hair.

This preparation is warrarted not to injure the hair ; it is used to prevent the hair from coming out, is a nice perfumed dressing fo: the hair, and though it does not stain the fingervi or skin, it will make Gray Hair beautifully Brown or Black, as may be desired. Price, 30 cents a paukags, or four for $\$ 1.00$, sent free of postage.

Send cash to Dr. M. L. BYRN, Box 1,689 , Paal Office, New York City, (office so Cedar streat.) 


\section{Catarih in the Head.}

This is characterized by a thick muo 'pur sieal matter, collecting in the posterior nares, sometimow extending to the frontal sinus (above the root of the nose), which is often discharged from the nose. or drawn down into the throat, and then spit out of the mouth, or as is often the case, accidentally swallowed ; and making its way into the stomach, often gives rise to derangement of the digestive orgaus, owing to the nausealing and fœtid odor of the matter. The breath sometimes becomes so unpleasant as to render the person unfit for society; there is a feeling of fullness and dryness in the roof of the mouth, throat, and posterior nares, and a frequent disposition to "clear the head and throat." The discharge, at first almost colorless, becomes after a time of a yellowish hue, and exceedingly offensive The disease. proceeding to the tube leading from the throat to the internal ear, makes the patient hard of hearing, with roaring or buzzing sound in the head. The general health soon becomos affeeted, the countenance becumes sallow, there is loss of appetite and wasting of the general strength, and loss of flesh. Unless cured, the disease often follows the sufferer to the grave-but by proper treatment it can be cured.

Persons being afflicted as above described, by writing to me, giving particulars of their case, and enclosing FIVE DoLLARs, and 50 cents for postage, will receive by return of mail, medical treatment and Inlaler for this dilsease. Direct letters to M. L. BrRs, M. D., Box 4669 P. O., or call at

80 Cedar Street

from 9 A.M. to 4 P.M. 


\section{DR. II. I. BIRIJ'S}

Cellebrated

\section{Antidote for Tobacco!}

This is not a SUBSTItUTE, but A CURE, for Chew ing, Smoking, and Snuff-taking.

I have treated thousands of cases within the last twelve years, and cured them entirely, some of which have been using tobacco for twenty or thirty years. I use only vegetable remedies and warrant dem not to impair the system; and if taken according to my directions, a cure is guaranteed, and that Fithout inconvenierce or injury to the system.

This medicine is prepared to enable those who desire it, totally and in a few days time, to abandon the use of tobacco in any and every form. It is the means of destroying the longing or taste which perBons bave for tobacco, and thereby every one may abandon its use. Besides this, it acts as a tonic on the system, and also purifies the breath, leaving a pleasant taste in the mouth. It also regulates the bowels, and is an excellent correcter of the bile. It is sold at Firtr Crests a Package. In a great many cases one package is sufficient, but the best plan is to send $\$ 1.00$ for two packages so as to be sure. Five Packages for Two Dellatrs, or Fourteen Packages for Five Dollars sent free by mail-100 packages by express for $\$ 20$.

Send all orders to Dr. M. I B BRN, Box 4669 , P. O. New York City.

Few persons have any idea of the terrible effects of this noxious weed on the human system. Dyspepsia, Neuralgia. Headache, Disease of the Liver, Sallow Complexion, Costiveness of the Bowels, Nervousness, Loss of Memory, undue excitability of the system, as seen in peevishness, ungovernable tempers, impatience, restlessuess \&c, and other disesses are the affictions hrought on by its use. 


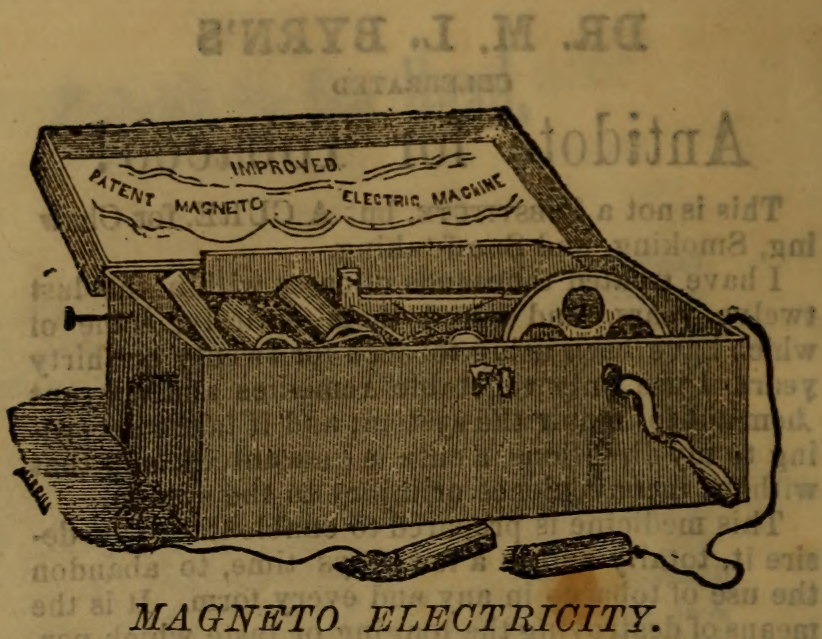

By means of the above MAGNETO-ELECTHIC MACHINE, many Chronic di eases can be healed tiat could not by any other system of medication. This machine produces Galvanic ElectriCITT, by simply turning a crank. It requires No BATTERY, NO EOLUTIONS, and No FRICTIONs, but developes Electı icity by what is called the INDUCTISE influence of a permanent magnet, and it gives a current of the same chiracter of the ELECrRo-magnetio machines, which require a battery to actuate them. The machine is SMALL, CONVENIENT, being enclosed in a brass-cornered mahogany box, and, with good care, will last a life-tiuse. There is a "Book of Directions" for operating the machine, and every thing complete for treating all the varions forms of diseases that goes gratis with each machine sold. Price of machine, all coms plete, $\$ 12$. No. Send cash to UR. M. L. BYRN, Box 4,669 , Post Office New York City. Ofice, 80 Cedar street.

\section{How to make money with this Macliine.}

By purchasing ore of these machines, and getting well acquainted with its operations, and getting out some little handbills or advertise in the local newspaper. offering to apply Medical Electricity to those who are sick, at 10 or 15 cents for ea-h application. In this way you may soon get a run of custom, and that which pays ; for persons who feel benefitted by it will continue to come trom day to day, and receive an application of the remedy. And also a great many persons out of mere ctriosity, will " take a shock" or twio ; in many cases you can olten get up a club of ten or fifteen persons, and apply the Electricity to all at once, by uniting their hands together and forming a circle.No investment of $\$ 12$ will pay a young man better than one of these machines, operated in this way ; it will give a fine opportr. nity for travelling and seeing the world and making money at tb same time.

Any person desiring further particulars, wil please adr NR. M. I. BYRN. Box 4,669 P. O. New York, or call ai. fice, so Cedar street. 



\section{LIBRARY OF C,ONGRESS}

THP MYS'ERY OF MEL A Family Physician \& $\mathrm{H}_{1}$ Prupared for the us: of Familien, Plans M. LA FA Y E I' ' I I

Graduats of the Univers ty of New York, "Aathor of Poison, in our Food," kc. A Book of this kind has long been needed.

It has been writeu for the "People!" in plain lauguage so" as to be easily underwiood.

Tue treatwent recommended is muld, and the remedies preBeribed are such as sre well kuown lo the Medical Facuity. andaresmpLE and sare aud to be obtaiued at any ordinary druy store. It gives ail necessary information withont using Medical terms, and 18. beyoua doubt, wis best fromily baewor Book that nas efer been publisbed. It is iutended as a guide for preserviug health and prolunging live, by givisg that kina of iniormation , coucheu in laug gatge ti ee from nedical tech. uicalities), which lias long been ueeded by the masses. The object has beeri no. ouly to simplify the law of healh and phy. wical educestion, but to give such plan descr jtiojs us tie various alments which oar bodies are wubject to, thab every one way know from the symptcmis ea h allment or disease a.d bo ellobled to give the beat remedies, wheru a pliysician caunot be had, or, in cases of emergency, to know what to do beforia a physiclan arrdves, su as to allevia e sufferng or to be the weans on saving life.

\section{RECO M MEN DATHO A \\ From Minisiers of the Goxpel and ofkers}

Qha boban it may soncern:

We the subscribers having read In syristiew wedical buok, take pleasuro in reconuenuing it to the puulue s we ruily Work worthy of patronage.

Rkv. WALTER CHAMBERLIN, Perth Ambuy, New Jerisey. REV. J. H. UAILLY, Woodbrid e, New Jersey, REv. J. COWLNS. Hackensack, New Jercey

KIV. H, C. PARRAR, A B. Waterfora, New York.

REv, K. H. RUBINSUN. Ballston Spa, New York. REv. U. W. UOWNS, King atou, New Hampkhre. Kev. G. W. UARR, Ussippee, New Hampshire. REv, S. H. ONUXKE, Tottenville New Yurk, REv, G, W.TREAT, Rahway, N.J. Rev, A. L'SANFORi. N Y. BEv. J. L. KACE, Bethany, Pa, Rev. T, M. UURRY, N. X

The Christian Guandax, Turonto, Canada, вay :

"It is plain and simple in its otyle, giving nos-profesciona! reade

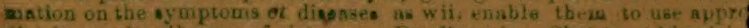
diee in nearly all cases of sickue-s. Dr. Byro is a Christran khysicie mistake nos; s mearber of the M. E. Church, and has done a noble Nllow men in the publication of this work, which would bless overy

The Book is a large Oetavo volume of 473 pages, $p$ new and handsome type, on heavy paper, and i with numerous finely-executed engravings, amony finely tinted lithographs.

Price, bound in extra cloth

With the view of introducing the book a 8 AMPI sent free by rail for $\$ 1.80$. P A GeNTs W AxTED; dddress all orders to DR. M. L. BYRN. No. 80 York. P. O. Box $\$ 669$. 